\title{
Pendidikan Konservasi Satwa Endemik Sulawesi bagi Siswa Sekolah Dasar di Kelurahan Batuputih Bawah, Kecamatan Ranowulu, Kota Bitung, Sulawesi Utara
}

\author{
Saroyo1*, Parluhutan Siahaan ${ }^{1}$, Marnix L.D.Langoy ${ }^{1}$, dan Roni Koneri ${ }^{1}$ \\ ${ }^{1}$ Jurusan Biologi, Fakultas Matematika Dan Ilmu Pengetahuan Alam \\ Universitas Sam Ratulangi \\ *Penulis Korespondensi, Saroyo, Program Studi Biologi, Fakultas Matematika dan Ilmu Pengetahuan Alam, \\ Universitas Sam Ratulangi, Jl. Kampus Unsrat manado 95115, E-mail: saroyo@unsrat.ac.id
}

\begin{abstract}
ABSTRAK
Pulau Sulawesi memiliki kekayaan hayati dan endemisitas satwa yang sangat unik yang merupakan percampuran antara flora dan fauna khas Asia dan Australia. Beberapa kawasan yang menyimpan kekayaan hayati endemik Sulawesi telah berstatus sebagai kawasan konservasi, antara lain Cagar Alam Dua Sudara, Taman Wisata Alam Batuputih, dan Taman Wisata Alam Batuangus di Kota Bitung, Sulawesi Utara. Hanya sayangnya, banyak kekayaan hayati di Sulawesi Utara yang sedang menghadapi kepunahan akibat faktor perburuan untuk konsumsi dan perusakan habitat. Oleh karena itu kegiatan pendidikan konservasi bagi anak-anak sekolah dasar menjadi upaya yang sangat penting dan harus dilakukan dengan bekerjasama dengan mitra-mitra potensial. Kegiatan pendidikan konservasi untuk murid sekolah dasar di sekitar kawasan konservasi telah dilaksanakan pada tanggal 3 Agustus 2018 di Kelurahan Batuputih Bawah, Kecamatan Ranowulu, Kota Bitung. Peserta sebanyak 26 siswa sekolah dasar kelas 4 sampai dengan kelas 6. Tujuan kegiatan ini ialah memberikan pengetahuan tentang konservasi sumber daya alam hayati untuk murid-murid sekolah dasar sehingga terjadi perubahan pengetahuan dan sikap dalam menghentikan praktik perburuan dan perusakan habitat sumber daya alam hayati. Metode yang diterapkan dalam kegiatan ini ialah workshop tentang keragaman satwa endemik Sulawesi di Kota Bitung, dan pengenalan terhadap jenis-jenis satwa kunci Sulawesi. Evaluasi keberhasilan kegiatan dilakukan dengan pretes dan postes untuk menganalisis peningkatan pengetahuan dan sikap terhadap aspek konservasi sumber daya alam hayati Sulawesi. Untuk mengukur sikap digunakan kuesioner dengan skala Likert. Komponen evaluasi mencakup aspek kognitif (pengetahuan/penguasaan materi) dan afektif (penguasaan sikap). Hasil kegiatan menunjukkan terjadinya peningkatan pengetahuan dari 6,0 menjadi 7,8 sedangkan sikap dari 5,6 menjadi 8,0. Dari hasil kegiatan tersebut di atas dapat disimpulkan bahwa kegiatan pendidikan konservasi bagi anakanak usia sekolah dasar telah meningkatkan pengetahuan dan sikap positif terhadap konservasi sumber daya alam hayati Sulawesi bagi peserta.
\end{abstract}

Kata kunci: pendidikan, usia sekolah dasar, konservasi, Kota Bitung, Sulawesi Utara

\section{PENDAHULUAN}

\section{Analisis Situasi}

Pulau Sulawesi merupakan salah satu Subkawasan Wallacea yang memiliki peran penting dalam mempertahankan keragaman hayati. Sebagai bagian dari Kawasan Wallacea, Sulawesi memiliki kekayaan hayati yang tinggi dan beberapa di antaranya bersifat endemik. Beberapa contoh satwa endemik Sulawesi ialah monyet Sulawesi (Genus Macaca), babirusa (Babyrousa babyrussa), anoa dataran tinggi (Bubalus quarlesi), anoa dataran rendah (Bubalus depressicornis), musang Sulawesi (Macrogalidia musschenbroeckii), kuskus beruang (Ailurops ursinus), kuskus kerdil (Strigocuscus celebensis), tangkasi (Tarsius spectrum), tangkasi Sangir (Tarsius sangiriensis), burung maleo (Macrocephalon maleo), dan burung rangkong (Rhyticeros cassidix) (Kinnaird, 1997; Lee et al., 2001).

Salah satu lokasi yang masih menyimpak kekayaan hayati ini ialah Kota Bitung di Provinsi Sulawesi Utara. Pada lokasi ini terdapat tiga kawasan konservasi, yaitu Cagar Alam Dua Sudara, Taman Wisata Alam Batuputih, dan Taman Wisata Alam Batuangus. Kawasan konservasi tersebut sampai saat ini disebut 
sebagai kawasan konservasi yang paling aman karena masih menyimpan beberapa satwa endemik Sulawesi utama, yaitu monyet hitam sulawesi (Macaca nigra), anoa dataran rendah, musang sulawesi, kuskus beruang, kuskus kerdil, burung maleo, julang sulawesi, dan kangkareng sulawesi (Rhabdotorrhinus exarhatus).

Walaupun sering disebut kawasan paling aman di Sulawesi Utara, kawasan konservasi di Kota Bitung memiliki dua permasalahan utama, yaitu perburuan terutama untuk dikonsumsi dan perusakan habitat. Permasalahan pertama dianggap sebagai penyebab utama penurunan populasi satwa liar, terutama monyet hitam sulawesi dan musnahnya secara lokal babirusa. Survei oleh Saroyo (2011) dan Saroyo \& Koneri $(2011,2012)$ mengindikasikan masih terdapatnya ancaman yang serius pada kawasan ini, yaitu perusakan habitat burung serta perburuan burung. Oleh karena itu perlu dilaksanakan upaya-upaya dalam peningkatan kesadaran masyarakat akan pentingnya keragaman burung dan kelestariannya. Oleh karena itu peran berbagai pihak sangat penting untuk terlibat dalam upaya sosialisasi konservasi ini, antara lain perusahaan, dan organisasi konservasi/pencinta alam.

Salah satu sebab munculnya ancaman terhadap satwa endemik Sulawesi di Kota Bitung ialah rendahnya pemahaman akan pentingnya keberadaan satwa tersebut serta upaya konservasinya.

Pendidikan pada usia anak merupakan tahapan penting di dalam pembentukan karakter (Sakti, 2017). Pada usia tersebut, anak dapat melakukan identifikasi dengan mengamati karakteristik nilai sosial melalui proses pembelajaran (Rachman, 2013). Dengan karakteristik mereka, pembelajaran melalui interaksi sosial yang menyenangkan akan memiliki pengaruh yang positif dalam menanamkan nilai-nilai tertentu, misalnya penghargaan akan keberagaman makhluk hidup, manfaat, serta upaya konservasinya.

Dengan latar belakang tersebut di atas, telah dilaksanakan kegiatan pendidikan konservasi satwa endemik Sulawesi bagi siswa sekolah dasar di Kelurahan Batuputih Bawah, Kecamatan Ranowulu, Kota Bitung, Sulawesi Utara.

\section{Tujuan dan Manfaat Kegiatan}

Kegiatan tentang pendidikan konservasi satwa endemik Sulawesi bagi siswa Sekolah
Dasar di Kelurahan Batuputih Bawah, Kecamatan Ranowulu, Kota Bitung, Sulawesi Utara bertujuan untuk menanamkan pengetahuan tentang keragaman satwa endemik Sulawesi sekaligus dan upaya konservasinya.

Manfaat kegiatan dapat ditinjau dari aspek kognitif dan afektif peserta. Dari aspek kognitif, kegiatan bermanfaat di dalam meningkatkan pengetahuan akan keragaman hayati satwa endemik Sulawesi dan konservasinya di Kota Bitung. Dari aspek afektif, kegiatan bermanfaat dalam mentransformasikan perubahan sikap menjadi positif dalam memandang keberadaan satwa endemik Sulawesi serta upaya-upaya konservasinya.

\section{METODE PELAKSANAAN}

\section{Sasaran kegiatan}

Peserta dalam kegiatan ini ialah 25 orang siswa sekolah dasar di Kelurahan Batuputih Bawah, Kecamatan Ranowulu, Kota Bitung. Kelompok masyarakat ini secara ekonomi tidak produktif tetapi memiliki posisi dan peran strategis dalam perubahan pengetahuan dan sikap tentang konservasi sumber daya alam hayati di Sulawesi Utara. Target hasil kegiatan ialah terjadinya peningkatan pengetahuan dan perubahan sikap dalam konservasi sumber daya alam hayati di Sulawesi Utara terutama dalam menghentikan perburuan untuk konsumsi dan perusakan habitat.

\section{Lokasi kegiatan}

Kegiatan workshop dan pengenalan lapangan dilaksanakan di Kelurahan Batuputih Bawah serta Taman Wisata Alam Batuputih, Kecamatan Ranowulu, Kota Bitung.

\section{Metode yang digunakan :}

Kegiatan pendidikan konservasi dilaksanakan melalui tahap-tahap sebagai berikut ini. Wokshop dilaksanakan di Kelurahan Batuputih Bawah. Materi workshop meliputi keanekaragaman satwa endemik Sulawesi di Kota Bitung, ancaman terhadap kelangsungan hidup keanekaragaman hayati, dan upaya konservasinya. Pengenalan satwa-satwa endemik utamanya dengan menggunakan kunci identifikasi dan gambar, yang mencakup jenisjenis berikut ini: 
Tabel 1. Daftar Hewan Endemik Sulawesi

\begin{tabular}{|c|c|c|c|c|c|c|c|}
\hline No. & Jenis & Nama Lokal & $\begin{array}{l}\text { Nama } \\
\text { Inggris }\end{array}$ & Endemisitas & $\begin{array}{l}\text { PP No. } \\
7 / 1999\end{array}$ & $\begin{array}{c}\text { Kategori } \\
\text { oleh } \\
\text { IUCN }\end{array}$ & CITES \\
\hline 1. & Macaca nigra & Yaki & $\begin{array}{l}\text { Sulawesi } \\
\text { Crested } \\
\text { Black } \\
\text { Macaque }\end{array}$ & $\begin{array}{l}\text { Semen } \\
\text { Minaha }\end{array}$ & Dilindungi & Kritis & $\begin{array}{c}\text { Appendix } \\
\text { II }\end{array}$ \\
\hline 2. & $\begin{array}{l}\text { Tarsius } \\
\text { spectrum }\end{array}$ & Tangkasi & $\begin{array}{l}\text { Spectral } \\
\text { Tarsier }\end{array}$ & $\begin{array}{l}\text { Subka } \\
\text { Sulaw }\end{array}$ & Dilindungi & Rentan & $\begin{array}{l}\text { Appendix } \\
\text { II }\end{array}$ \\
\hline 3. & $\begin{array}{l}\text { Bubalus } \\
\text { depressicornis }\end{array}$ & $\begin{array}{l}\text { Anoa } \\
\text { Dataran } \\
\text { Rendah }\end{array}$ & $\begin{array}{l}\text { Lowland } \\
\text { Anoa }\end{array}$ & $\begin{array}{l}\text { Subkawasan } \\
\text { Sulawesi }\end{array}$ & Dilindungi & Genting & $\begin{array}{l}\text { Appendix } \\
\text { I }\end{array}$ \\
\hline 4. & $\begin{array}{l}\text { Babyrousa } \\
\text { babyrussa } \\
\text { celebensis }\end{array}$ & $\begin{array}{l}\text { Babirusa } \\
\text { Sulawesi }\end{array}$ & $\begin{array}{l}\text { Celebes } \\
\text { Babirusa }\end{array}$ & $\begin{array}{l}\text { asan } \\
\text { i }\end{array}$ & ungi & an & $\begin{array}{l}\text { Appendix } \\
\text { I }\end{array}$ \\
\hline 5. & Ailurops ursinus & $\begin{array}{l}\text { Kusk } \\
\text { Berua }\end{array}$ & $\begin{array}{l}\text { Bear } \\
\text { Cuscus }\end{array}$ & $\begin{array}{l}\text { asan } \\
\text { i }\end{array}$ & - & Rentan & - \\
\hline 6. & $\begin{array}{l}\text { Strigocuscus } \\
\text { celebensis }\end{array}$ & $\begin{array}{l}\text { Kuskus } \\
\text { Kerdil }\end{array}$ & $\begin{array}{l}\text { Sulawesi } \\
\text { Cuscus }\end{array}$ & $\begin{array}{l}\text { Subkawasan } \\
\text { Sulawesi }\end{array}$ & Dilindungi & Rentan & - \\
\hline 7. & $\begin{array}{l}\text { Macrogalidia } \\
\text { musschenbroekii }\end{array}$ & $\begin{array}{l}\text { Musang } \\
\text { Sulawesi }\end{array}$ & $\begin{array}{l}\text { Brown } \\
\text { Palm } \\
\text { Civet }\end{array}$ & $\begin{array}{l}\text { Subkawasan } \\
\text { Sulawesi }\end{array}$ & Dilindungi & Rentan & $\begin{array}{l}\text { Appendix } \\
\text { II }\end{array}$ \\
\hline 8. & $\begin{array}{l}\text { Macrocephalon } \\
\text { maleo }\end{array}$ & $\begin{array}{l}\text { Maleo } \\
\text { Senkawor }\end{array}$ & Maleo & $\begin{array}{l}\text { Subkawasan } \\
\text { Sulawesi }\end{array}$ & Dilindungi & Genting & $\begin{array}{l}\text { Appendix } \\
\text { I }\end{array}$ \\
\hline 9. & Aceros cassidix & $\begin{array}{l}\text { Julang } \\
\text { Sulawesi }\end{array}$ & $\begin{array}{l}\text { Red } \\
\text { Knobbed } \\
\text { Hornbill } \\
\end{array}$ & $\begin{array}{l}\text { Subkawasan } \\
\text { Sulawesi }\end{array}$ & Dilindungi & $\begin{array}{c}\text { Kurang } \\
\text { Perhatian }\end{array}$ & $\begin{array}{c}\text { Appendix } \\
\text { II }\end{array}$ \\
\hline 10. & $\begin{array}{l}\text { Penelopides } \\
\text { exarhatus }\end{array}$ & $\begin{array}{l}\text { Kangkareng } \\
\text { Sulawesi }\end{array}$ & $\begin{array}{l}\text { Sulawesi } \\
\text { Hornbill }\end{array}$ & $\begin{array}{l}\text { Subkawasan } \\
\text { Sulawesi }\end{array}$ & Dilindungi & $\begin{array}{c}\text { Kurang } \\
\text { Perhatian }\end{array}$ & $\begin{array}{c}\text { Appendix } \\
\text { II }\end{array}$ \\
\hline
\end{tabular}




\section{HASIL DAN PEMBAHASAN}

Hasil kegiatan menunjukkan terjadinya peningkatan pengetahuan dari 6,0 menjadi 7,8 sedangkan sikap dari 5,6 menjadi 8,0, yang menunjukkan bahwa kegiatan pendidikan konservasi bagi anak-anak usia sekolah dasar di Kelurahan Batuputih Bawah, Kecamatan, Ranowulu, Kota Bitung, Sulawesi Utara telah meningkatkan pengetahuan dan sikap positif terhadap konservasi sumber daya alam hayati Sulawesi bagi peserta.

Pendidikan konservasi yang

dilaksanakan pada usia dini sangat berperan penting dalam pembentukan karakter masyarakat di masa yang akan datang. Memang ada perbedaan pengertian istilah usia dini. Menurut Peraturan Pemerintah Republik Indonesia Nomor 17 Tahun 2010 tentang Pengelolaan dan Penyelenggaraan Pendidikan, pendidikan anak usia dini adalah suatu upaya pembinaan yang ditujukan kepada anak sejak lahir sampai dengan usia 6 (enam) tahun yang dilakukan melalui pemberian rangsangan pendidikan untuk membantu pertumbuhan dan perkembangan jasmani dan rohani agar anak memiliki kesiapan dalam memasuki pendidikan lebih lanjut. Batasan ini berbeda dengan konvensianak dunia yang menetapkan rentang usia dini dari 0 hingga 8 tahun (Fakhruddin, 2009). Oleh karena itu, Judiani (2010) menekankan bahwa pembinaan karakter secara mudah dilakukan pada saat anak masih duduk di sekolah dasar. Pembangunan karakter ini menjadi landasan yang penting dalam pencapaian aspek afektif anak, di samping aspek kognitif atau intelektualitas dan aspek psikomotorik atau keterampilan. Akbar et al. (2014) menyatakan bahwa pendidikan karakter dapat dibangun melalui pembelajaran kelas, kultur satuan pendidikan, kegiatan ekstrakurikuler, dan pelibatan peran orang tua dan masyarakat dapat menumbuhkan karakter yang baik pada pensisikan dasar.

Berkaitan dengan tujuan kegiatan pendidikan konservasi satwa endemik Sulawesi di Kelurahan Batuputih Bawah, Kecamatan Ranowulu, Kota Bitung, Sulawesi Utara, sasaran kegiatannya juga anak usia sekolah dasar mengingat pendidikan usia tersebut merupakan masa pembangunan karakter atau kepribadian yang penting selama tumbuh dan berkembangnya seseorang. Pendidikan konservasi berhubungan erat dengan lingkungan hidup yang secara umum didefinisikan sebagai Lingkungan hidup adalah kesatuan ruang dengan semua benda, daya, keadaan, dan makhluk hidup, termasuk manusia dan perilakunya, yang mempengaruhi alam itu sendiri, kelangsungan perikehidupan, dan kesejahteraan manusia serta makhluk hidup lain (UU No. 32 tahun 2009). Dalam definisi tersebut, perilaku manusia merupakan komponen penting dalam kesatuan semua komponen yang membentuk lingkungan hidup.

Salah satu isu penting dalam lingkungan hidup ialah konservasi keragaman hayati atau biodiversitas. Dalam Undang-Undang Republik Indonesia Nomor 5 Tahun 1990 tentang Konservasi Sumber Daya Alam Hayati dan Ekosistemnya telah dijelaskan beberapa hal. Sumber daya alam hayati adalah unsur-unsur hayati di alam yang terdiri dari sumber daya alam nabati (tumbuhan) dan sumber daya alam hewani (satwa) yang bersama dengan unsur nonhayati di sekitarnya secara keseluruhan membentuk ekosistem. Konservasi sumber daya alam hayati adalah pengelolaan sumber daya alam hayati yang pemanfaatannya dilakukan secara bijaksana untuk menjamin kesinambungan persediaannya dengan tetap memelihara dan meningkatkan kualitas keanekaragaman dan nilainya.

Permasalahan konservasi terbesar di Sulawesi Utara ialah perburuan satwa liar untuk dikonsumsi. Survei oleh Saroyo (2011) menunjukkan bahwa sejumlah satwa liar dari kelas mamalia, burung, dan reptil telah diburu dan dikonsumsi oleh sebagian masyarakat. Berbagai studi juga menunjukkan bahwa perburuan ini merupakan faktor yang bertanggung jawab atas menurunnya populasi berbagai satwa liar di Sulawesi Utara, termasuk yaki di Bitung dan hilangnya babirusa di kawasan konservasi di Kota Bitung tersebut. Oleh karena itu, berbagai upaya harus dilakukan dalam upaya konservasi, termasuk pendidikan karakter pentingnya pengetahuan dan sikap tentang konservasi. Pendidikan konservasi alam pada akhirnya akan menunjang pembangunan berkelanjutan (Soenarno, 2016). Yuniawan (2016) menekankan model wacana berwawasan nilai-nilai konservasi berbasis ekolinguistik sebagai pengayaan materi ajar mata kuliah pendidikan lingkungan hidup. Lebih lanjut Jayawardana (2016) menyatakan bahwa habituasi atau pembiasaan dalam perkembangan 
anak akan berlangsung secara terus menerus sehingga akan menjadi karakter yang ditunjukkan atau dilaksanakan dalam kehisupan sehari-hari sehingga dapat berdampak positif bagi pelestarian lingkungan hidup.

\section{KESIMPULAN DAN SARAN}

\section{Kesimpulan}

Dari hasil kegiatan tersebut di atas dapat disimpulkan bahwa kegiatan pendidikan konservasi bagi anak-anak usia sekolah dasar di Kelurahan batuputih Bawah, Kecamatan, Ranowulu, Kota Bitung, Sulawesi Utara telah meningkatkan pengetahuan dan sikap positif terhadap konservasi sumber daya alam hayati Sulawesi bagi peserta.

\section{Saran}

Perlu dilaksanakan pelatihan di lapangan untuk melengkapi keterampilan dalam pengenalan jenis satwa endemik dengan lebih baik.

\section{UCAPAN TERIMAKASIH}

Kegiatan ini terlaksana atas bantuan dari berbagai pihak. Oleh karena itu, penulis mengucapkan banyak terima kasih kepada Rektor Universitas Sam Ratulangi, Ketua Lembaga Penelitian dan Pengabdian kepada Masyarakat, Dekan Fakultas Matematika dan Ilmu Pengetahuan Alam Universitas Sam Ratulangi, Pemerintah Kota Bitung, Kepala Balai Konservasi Sumber Daya Alam (BKSDA) Sulawesi Utara, Masyarakat Kelurahan Batuputih Bawah, Kedua Mitra, yaitu Kelompok Pemandu Wisata Alam Tangkoko, serta Kelompok Pencinta Alam Tarantula.

\section{DAFTAR PUSTAKA}

Akbar, S., A. Samawi, M. Arafiq, \& L. Hidayah. 2014. Model Pendidikan Karakter yang Baik (Studi Lintas Situs Bests Practices) Pendidikan Karakter Di SD. Sekolah Dasar 23 (2): 139-151.
Fakhruddin, A.U. 2009. Pendidikan Anak Usia Dini sebagai Alas Pendidikan. Insania 14, (2) : 231-241.

Jayawardana, H.B.A. 2016. Pendidikan Karakter Peduli Lingkungan Sejak Dini sebagai Upaya Mitigasi Bencana Ekologis. Prosiding Symbion (Symposium on Biology Education), Prodi Pendidikan Biologi, FKIP, Universitas Ahmad Dahlan.

Judiani, S. 2010. Implementasi Pendidikan Karakter di Sekolah Dasar Melalui Penguatan Pelaksanaan Kurikulum. Jurnal Pendidikan dan Kebudayaan 6 (9): 280289.

Kinnaird MF. 1997. Sulawesi Utara: Sebuah Panduan Sejarah Alam. Percetakan Redikencana. Jakarta.

Lee, R.J., J. Riley, \& R. Merrill. 2001. Keanekaragaman Hayati dan Konservasi di Sulawesi Bagian Utara. Wildlife Conservation Societies (WCS), Natural Resources, dan Departemen Kehutanan. Jakarta.

Rachman, M. 2013. Pengembangan pendidikan karakter berwawasan konservas inilai-nilai sosial. FIS 40 (1): 1-15.

Sakti, B.P. 2017. Indikator Pengembangan Karakter Siswa Sekolah Dasar. Magistra 29 (101): 1-10.

Saroyo. 2011. Konsumsi Mamalia, Burung, dan Reptil Liar pada Masyarakat Sulawesi Utara dan Aspek Konservasinya. Jurnal Bios Logos 5 (1): 25-31.

Saroyo \& R. Koneri. 2011. Pemetaan Distribusi dan Estimasi Populasi Monyet Hitam Sulawesi (Macaca nigra) di Sulawesi Utara dan Maluku Utara untuk Menentukan Status Konservasinya. Laporan Hasil Penelitian Hibah Kompetensi. Lembaga Penelitian. Universitas sam Ratulangi. Manado.

Saroyo \& R. Koneri. 2012. Konservasi Primata Endemik Nokturnal, Tangkasi (Tarsius 
spectrum), Melalui Kajian Distribusi dan Estimasi Populasi di Sulawesi Utara. Laporan Hasil Penelitian Hibah Kompetensi. Lembaga Penelitian Universitas Sam Ratulangi. Manado.

Saroyo \& R. Koneri. 2013. Konservasi Primata Endemik Nokturnal, Tangkasi (Tarsius spectrum), Melalui Kajian Distribusi dan Estimasi Populasi di Sulawesi Utara. Laporan Hasil Penelitian Hibah Kompetensi. Lembaga Penelitian Universitas Sam Ratulangi. Manado.

Soenarno, S.M. 2016. Pembelajaran Konservasi Alam dalam Menunjang Pembangunan Berkelanjutan. Prosiding Seminar Nasional II Tahun 2016, Kerjasama Prodi Pendidikan Biologi FKIP dengan Pusat Studi Lingkungan dan Kependudukan (PSLK) Universitas Muhammadiyah Malang. Malang.

Undang-Undang Republik Indonesia Nomor 5 Tahun 1990 Tentang Konservasi Sumber Daya Alam Hayati Dan Ekosistemnya.

Undang-Undang Republik Indonesia Nomor 32 Tahun 2009 tentang Perlindungan dan Pengelolaan Lingkungan Hidup. Lembaran Negara Republik Indonesia Tahun 2009 Nomor 140.

Yuniawan, T. 2016. Model Wacana Berwawasan Nilai-Nilai Konservasi Berbasis Ekolinguistik Sebagai Pengayaan Materi Ajar Mata Kuliah Pendidikan Lingkungan Hidup. Jurnal Penelitian Pendidikan 33 (2): 189-195. 
Lampiran: Alat evaluasi terhadap aspek kognitif dan afektif peserta

\section{Soal Pengetahuan:}

Pilih satu jawaban yang benar untuk soal-soal di bawah ini:

1. Hewan ini terdapat di Cagar Alam Tangkoko (Dua Sudara):
a. Gajah
b. Yaki

2. Contoh hewan yang dilindungi:
a. Sapi
b. Burung rangkong (taung)

3. Yaki bertempat tinggal di:
a. Hutan
b. Kebun

4. Yang termasuk hewan malam ialah:
a. Tarsius
b. Maleo

5. Monyet yang hanya ditemukan di Provinsi Sulawesi Utara ialah
a. Macaca maura
c. Macaca hecki
b. Macaca nigra
d. Macaca tonkeana

6. Burung yang meletakkan telurnya di tanah agar menetas ialah
a. Maleo
b. Julang Sulawesi / rangkong

7. Tarsius yang ada di Cagar Alam Tangkoko (Dua Sudara) bermanfaat untuk:
a. Menarik turis
b. Sumber makanan

8. Contoh hewan yang tidak dilindungi ialah
a. Maleo
b. Babi hutan

9. Kawasan konservasi yang berada di Kota Bitung:
a. Hutan Lindung Gunung Klabat
b. Taman Wisata Alam Batuputih

10. Termasuk tindakan konservasi ialah:
a. Memadamkan api di hutan
b. Berburu babi hutan

\section{Soal Sikap:}

Pilih satu jawaban yang benar untuk soal-soal di bawah ini:

1. Setujukan Anda jika ada orang memburu yaki dan hewan dilindungi lainnya?
a. Setuju
b. Tidak setuju

2. Setujukan Anda jika ada orang yang menjual daging yaki dan hewan dilindungi lainnya?
a. Setuju
b. Tidak setuju

3. Setujukan Anda jika ada orang yang memakan daging yaki dan hewan dilindungi lainnya?
a. Setuju
b. Tidak setuju

4. Setujukan Anda jika Anda terlibat dalam upaya pelestarian satwa di Tangkoko?

a. Setuju

b. Tidak setuju

5. Jika Anda pernah makan daging yaki dan hewan dilindungi lainnya, setujukan Anda jika Anda harus berhenti makan hewan tersebut?
a. Setuju
b. Tidak setuju 